\title{
Strength simulation tests of the load-bearing structure in a rail-road CLAAS ARION 610 tractor (pt. 1)
}

\author{
Symulacyjne badania wytrzymałości struktury nośnej dwudrogowego \\ ciągnika CLAAS ARION 610 (cz. 1)
}

\begin{abstract}
The article presents selected results of strength simulation tests of the load-bearing structure and coupling-buffer devices of a third-generation rail-road tractor built from the CLAAS ARION 610 agricultural tractor. Tests for the extraordinary load resistance of components of the front and rear train system were carried out in the aspect of the ability to absorb longitudinal loads and shocks in extreme conditions of tractor operation on the track.

It has been shown that the tested components of coupler-buffer devices meet the strength requirements at assumed extreme loads (300 kN compression, $150 \mathrm{kN}$ tensile), and after introducing a modernized front axle support they can withstand a compressive strength of up to $370 \mathrm{kN}$.

The second part of the article will be published in the next issue of the quarterly journal Rail Vehicles.
\end{abstract}

W artykule zaprezentowano wybrane wyniki symulacyjnych badań wytrzymałości struktury nośnej urzqdzeń pociagowo-zderznych ciagnika szynowo-drogowego trzeciej generacji zbudowanego na bazie ciagnika rolniczego CLAAS ARION 610. Przeprowadzono badania wytrzymałości na obciqżenia nadzwyczajne części składowych przedniego i tylnego układu pociagowego $w$ aspekcie zdolności konstrukcji do przejmowania obciażeń wzdlużnych $w$ ekstremalnych warunkach pracy ciagnika na torze.

Wykazano, że badane elementy składowe urzadzeń pociagowo-zderznych spetniaja wymagania wytrzymałościowe przy założonych obciqżeniach nadzwyczajnych (ściskanie $300 \mathrm{kN}$, rozciaganie $150 \mathrm{kN}$ ), a po wprowadzeniu zmodernizowanego wspornika przedniej osi osiagaja wytrzymałość na ściskanie do $370 \mathrm{kN}$.

Druga część artykutu zostanie opublikowana w kolejnym numerze kwartalnika Pojazdy Szynowe.

\section{Introduction}

Łukasiewicz Research Network - "TABOR" Rail Vehicles Institute is a designer and manufacturer of several dozen selected types of rail-road vehicles [3, $4,5,6,7,8]$, in particular rail-road tractors.

In 2015, the Rail Vehicles Institute "TABOR" in Poznań introduced into operation the third generation of its rail-road tractor manufactured as a modification of the series-produced CLAAS ARION 610 agricultural tractor. The CLAAS tractor was chosen among the many tractor manufacturers due to the favorable tractor design properties, especially as a tractor that can absorb longitudinal forces during operation on railway tracks.

\section{Wstęp}

Sieć Badawcza Łukasiewicz - Instytut Pojazdów Szynowych „TABOR” jest projektantem i wytwórcą kilkunastu wybranych rodzajów i typów pojazdów szynowo-drogowych $[3,4,5,6,7,8]$, w szczególności ciągników szynowo-drogowych.

W 2015 roku Instytut Pojazdów Szynowych „Tabor” w Poznaniu wprowadził do eksploatacji trzecią generację ciagnika szynowo-drogowego wytwarzanego na bazie seryjnie produkowanego ciagnika rolniczego typu CLAAS ARION 610. Spośród wielu producentów ciagników wybrano ciągnik firmy CLAAS ze względu na korzystne właściwości konstrukcji ciągnika, zwłaszcza zdolności ciągnika do przejmowa- 
An additional advantage in favor of choosing a CLAAS tractor was the commitment of CLAAS Polska to adapt the tractor to the Institute's requirements in terms of preparing it for adaptation for a rail-road tractor and maintaining the warranty for the base tractor even after its modification to a rail-road tractor.

The tractor has been factory-adapted to carry additional external loads. It was equipped with sets of frame reinforcements of the tractor's frame supporting elements, but still to an insufficient degree, especially at the front of the tractor, to meet the strength requirements set by the Institute.

Shunting traffic regulations require that when the traction vehicle reaches the wagons, the maximum vehicle speed is less than or equal to $3 \mathrm{~km} / \mathrm{h}$. At a run in speed of $3 \mathrm{~km} / \mathrm{h}$ a tractor with a mass of approx. 10 tons, the acceleration of incidence of $3 g$ was assumed on the wagons, which will generate the impact force of the tractor bumpers on the wagon bumpers with a value of about $300 \mathrm{kN}$.

The bearing structure of the tractor should therefore be adapted to absorb compressive forces not exceeding $300 \mathrm{kN}$.

Tensile forces were assumed to reach at most the level of $150 \mathrm{kN}$. The maximum tractive force of the tractor obtained during measurements carried out in IPS "TABOR" was about $55 \mathrm{kN}$ on dry rails with a vertical load of $5 \mathrm{kN}$ for each guide roller.

The axles of rail drive systems have a vertical load of $10 \mathrm{kN}$ for each axle. Vertical forces with a total value of $80 \mathrm{kN}$ remain on the tires.

The distribution of forces on the rail chassis rollers and tires as well as external longitudinal loads were shown in Figure 1, where they are marked accordingly as:

- $\mathrm{Q}_{1}=10 \mathrm{kN}$ - rail drive system force on the track

- $\mathrm{Q}_{2}=30 \mathrm{kN}$ - front axle tires force on the track

- $\mathrm{Q}_{3}=50 \mathrm{kn}-$ rear axle tires force on the track

- $\mathrm{P}_{1}=300 \mathrm{kN}$ - compressive force

$-\mathrm{P}_{2}=150 \mathrm{kN}-$ tensile force. nia sił wzdłużnych podczas eksploatacji na torach kolejowych.

Dodatkowym atutem przemawiającym za wyborem ciagnika firmy CLAAS było zobowiązanie CLAAS Polska do przystosowania ciagnika do wymagań Instytutu w zakresie przygotowania go do adaptacji na ciagnik dwudrogowy i utrzymania gwarancji na ciągnik bazowy po adaptacji na ciągnik szynowodrogowy.

Ciagnik został fabrycznie przystosowany do przenoszenia dodatkowych obciążeń zewnętrznych, przez wyposażenie $\mathrm{w}$ zespoły ramowych wzmocnień korpusów nośnych ciągnika, jednak w stopniu niewystarczającym, zwłaszcza z przodu ciagnika, do spełnienia wymagań wytrzymałościowych postawionych przez Instytut.

Przepisy dotyczące ruchu manewrowego stawiają wymaganie, aby podczas dojazdu pojazdu trakcyjnego do wagonów maksymalna prędkość pojazdu była mniejsza lub równa $3 \mathrm{~km} / \mathrm{h}$. Przy prędkości nabiegania $3 \mathrm{~km} / \mathrm{h}$ ciagnika o masie $\sim 10$ ton na wagony założono przyspieszenie nabiegania $3 \mathrm{~g}$, co wytworzy siłę uderzenia zderzaków ciągnika w zderzaki wagonów o wartości $\sim 300 \mathrm{kN}$.

Konstrukcja nośna ciągnika winna być zatem przystosowana do przejmowania sił ściskających o wartości nie przekraczającej $300 \mathrm{kN}$.

Siły rozciagające założono na maksymalnym poziomie $150 \mathrm{kN}$. Maksymalna siła pociagowa ciagnika uzyskana podczas przeprowadzonych w IPS „TABOR" pomiarów wynosi na suchych szynach $\sim 55 \mathrm{kN}$ przy obciążeniu pionowym $5 \mathrm{kN}$ każdej rolki prowadzącej.

Na osie szynowych układów jezdnych przypada obciążenie pionowe $10 \mathrm{kN}$ na każdą oś. Na oponach zaś pozostają siły pionowe o łącznej wartości $80 \mathrm{kN}$.

Rozkład sił na rolki szynowego układu jezdnego i opony oraz zewnętrzne obciążenia wzdłużne przedstawiono na rys. 1, gdzie odpowiednio oznaczono:

- $\mathrm{Q}_{1}=10 \mathrm{kN}$ - nacisk szynowego układu jezdnego na tor

- $\mathrm{Q}_{2}=30 \mathrm{kN}$ - nacisk opon przedniego mostu na tor

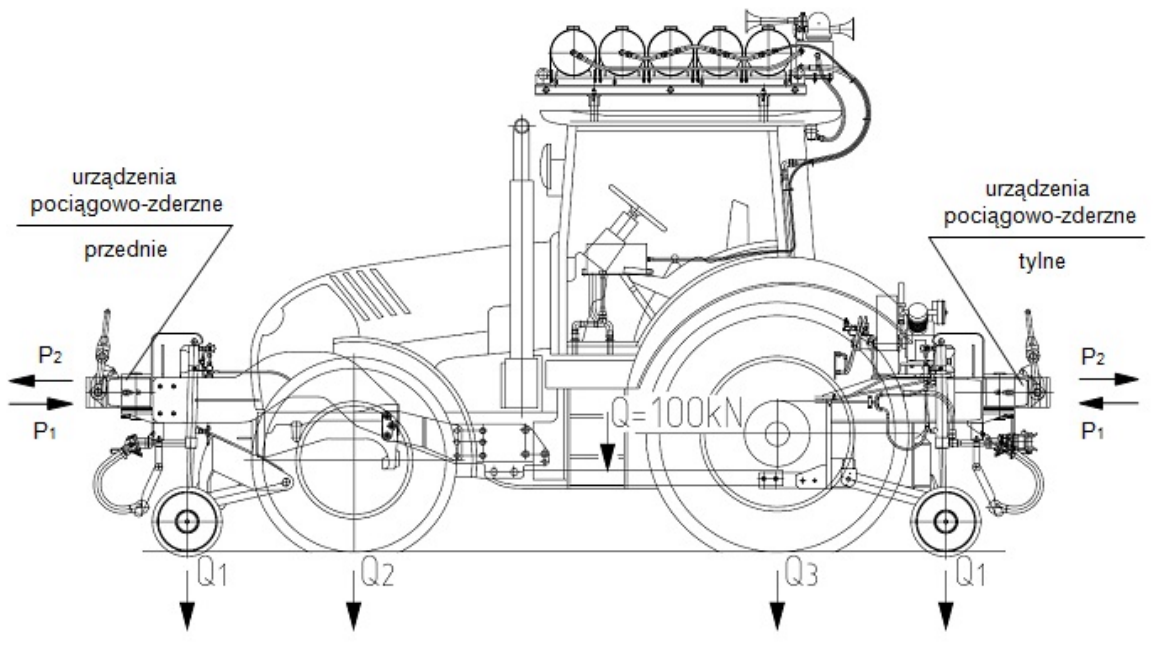

Rys. 1. Force distribution schematic for the tractor on rail

Descriptions: urządzenia ... przednie $=$ front coupling-buffer systems; urządzenia $\ldots$ tylne $=$ rear couplingbuffer systems

Rys.1. Widok boczny ciągnika 


\section{Tractor load bearing structure}

The model shown in Fig. 2 was the subject of simulation strength tests.

This model was built from the following structural elements:

- element 1 - factory made front axle support bracket

- element 2 - factory made side support bracket

- element 3 - additional side support elements

- element 4 - front chassis bracket

- element 5 - hind chassis bracket

- element 6 - bumper beam

- element 7 - cable hook.

The results of preliminary simulation tests revealed the insufficient strength of the factory-fitted supporting elements (elements 1 and 2) of the front coupling-buffer system, especially the front chassis bracket, which required the introduction of additional reinforcements of the front coupling-buffer system (element 3).

During the tractor manufacturing and assembly process, in order to strengthen the front load-bearing structure of the tractor, the manufacturer introduced structural changes to the front axle bracket and lateral reinforcements for mounting the axle bracket to the tractor engine body.
- $\mathrm{Q}_{3}=50 \mathrm{kn}$ - nacisk opon tylnego mostu na tor

- $\mathrm{P}_{1}=300 \mathrm{kN}$ - obciążenie ściskające

\section{Struktura nośna ciągnika}

Przedmiotem symulacyjnych badań wytrzymałościowych jest model przedstawiony na rys. 2 .

Model zbudowano z następujących elementów konstrukcyjnych:

- element nr 1 - fabryczny wspornik osi przedniej

- element nr 2 - fabryczne wzmocnienia boczne

- element nr 3 - dodatkowe wzmocnienie boczne

- element nr 4 - przednia skrzynia nośna

- element nr 5 - tylna skrzynia nośna

- element nr 6 - belka zderzakowa

- element $\mathrm{nr} 7$ - hak cięgłowy.

Wyniki wstępnych badań symulacyjnych wykazały niewystarczającą wytrzymałość fabrycznie zamontowanych elementów nośnych (element 1 i 2 ) przedniego układu pociaggowo-zderznego zwłaszcza wspornika przedniej osi, co wymagało wprowadzenia dodatkowych wzmocnień przedniego układu pociagoowozderznego (element nr 3).

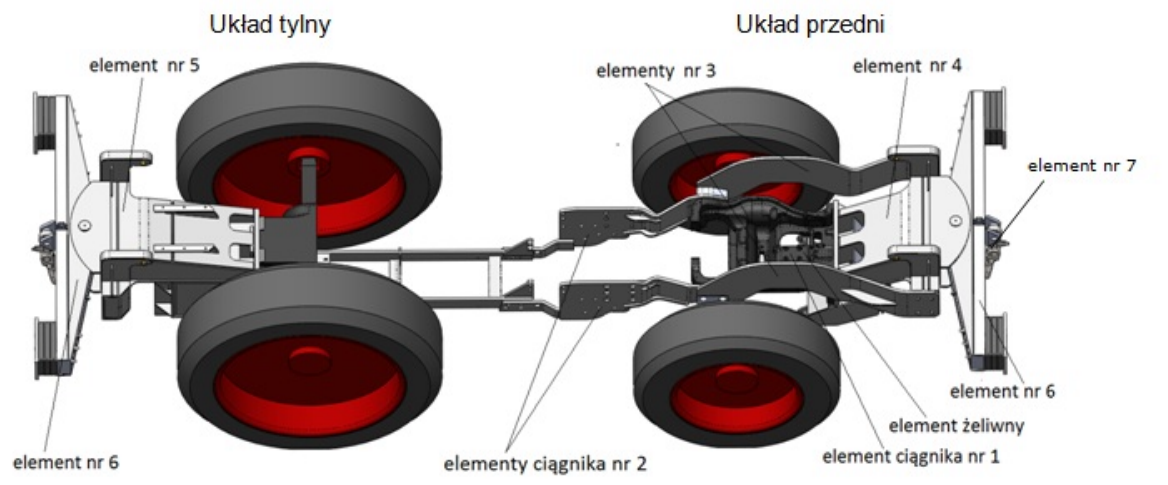

Rys.2. Chassis model

Descriptions: układ tylny = rear setup; układ przedni $=$ front setup; element $\mathrm{nr}=$ element no.; element żeliwny $=$ cast iron element; element ciagnika $=$ tractor element

Rys.2. Model struktury nośnej

The supporting structure of the front coupling-buffer system before and after modernization was shown in Fig. 3.

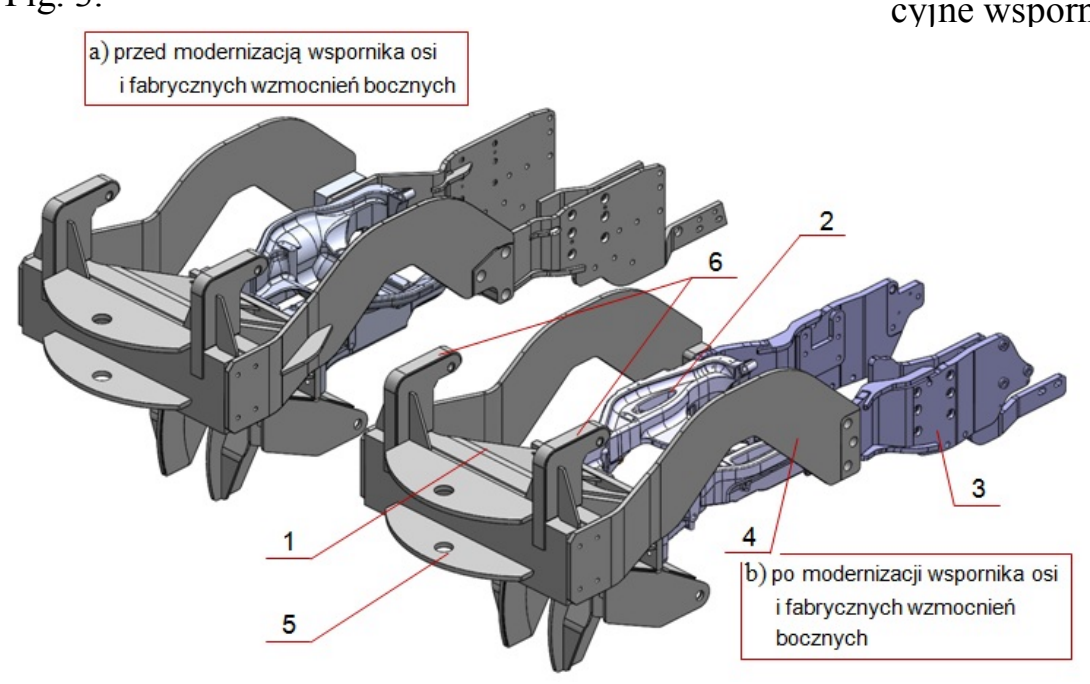

W trakcie procesu produkcji ciąnnika, w celu wzmocnienia przedniej struktury nośnej ciagnika, wytwórca ciagników wprowadził zmiany konstrukcyjne wspornika przedniej osi oraz bocznych
Rys.3. The basic support structure of the front coupling-buffer system Descriptions: a) przed $\ldots=$ before modernization of the axle support bracket and factory-made side brackets; b) po... = after modernization of the axle support bracket and factorymade side brackets

Rys. 3. Podstawowa struktura nośna przedniego układu pociagowozderznego 
The main impact-bearing element of the couplingbuffer system is the front chassis bracket $\mathbf{1}$ attached to the front surface of the factory axle support bracket $\mathbf{2}$, which is bolted to the engine body.

The axle bracket mounting to the engine body is factory-reinforced with appropriately shaped side beams 3. The axle bracket design is reinforced with additional upper side beams $\mathbf{4}$, which transfer some of the forces introduced into the axle bracket.

The flat chassis bracket structure $\mathbf{1}$ is equipped with brackets 5 to fix the bumper beam to as well as brackets $\mathbf{6}$ to attach the hydraulic actuators of the rail drive system. Horizontal loads are introduced into the chassis structure by means of brackets $\mathbf{5}$, and vertical loads from the pressure of the track rollers on the track rails along with upwards forces from the ground are transferred by means of the other brackets 6 .

\section{Criteria for assessing element strength and the expected forces}

Strength assessment covers the values of reduced stresses $\sigma_{\text {red }}$ in individual elements of the vehicle structure, which are determined in accordance with the Huber-Mises stress hypothesis form the distortion strain energy. Stress values should not exceed the permissible $\sigma_{\text {dop }}$ values.

However, when stresses are determined for plastic materials, the phenomenon of local stress concentration may not be taken into account. If the calculations include local stress concentrations, then theoretical stresses are permitted to exceed the yield strength or the theoretical yield strength at $0.2 \%$ elongation. Areas of local plastic deformation associated with stress concentration should, however, be small enough so that no significant permanent deformations remain after removing the forces.

It was assumed that the main construction material is type S355 steel. Strength properties of this type of steel were provided in Table 1 [1].

The permitted elasticity limit values for S355 steel, taking into account the safety factor $\mathrm{s}=1.15$ have been listed in Table 2 .

Tractor elements (front axle support) are made of EN-GJS 600-3 ductile iron. Table 3 presents its strength parameters.

Basic strength parameters of the material used in the construction of the drive system

Table 1

Podstawowe parametry wytrzymałości materiału zastosowanego $w$ budowie układu jezdnego Tablica 1

\begin{tabular}{|c|c|c|c|}
\hline Materiał & $\begin{array}{c}\text { Grubość elementu } \\
{[\mathrm{mm}]}\end{array}$ & Granica plastyczności $\mathrm{R}_{\mathrm{e}}[\mathrm{MPa}]$ & Wytrzymałość doraźna $\mathrm{R}_{\mathrm{m}}[\mathrm{MPa}]$ \\
\hline Material & $\begin{array}{c}\text { Element thickness } \\
{[\mathrm{mm}]}\end{array}$ & Yield strength limit $\mathrm{R}_{\mathrm{e}}[\mathrm{MPa}]$ & Ultimate strength $\mathrm{R}_{\mathrm{m}}[\mathrm{MPa}]$ \\
\hline \multirow{2}{*}{ S355 } & $<16$ & 355 & \multirow{2}{*}{$470 \div 630$} \\
\cline { 2 - 3 } & $16 \div 40$ & 345 & \\
\hline
\end{tabular}

wzmocnień mocowania wspornika osi do korpusu silnika ciągnika.

Strukturę nośną przedniego układu pociagowozderznego przed i po modernizacji przedstawiono na rys. 3.

Głównym elementem nośnym układu pociagowozderznego jest skrzynkowa konstrukcja 1 mocowana do czołowej powierzchni fabrycznego wspornika osi 2, który połączeniami śrubowymi jest mocowany do korpusu silnika.

Mocowanie wspornika osi do korpusu silnika fabrycznie wzmocniono odpowiednio ukształtowanymi blachami bocznymi 3. Konstrukcję wspornika osi wzmocniono dodatkowymi bocznymi blachami górnymi 4, które przenoszą część obciążeń wprowadzonych w wspornik osi.

Skrzynkową konstrukcję nośną 1 wyposażono we wsporniki 5 mocowania belki zderzakowej oraz wsporniki 6 mocowania siłowników hydraulicznych szynowego układu jezdnego. Obciążenia poziome są wprowadzone w konstrukcję skrzynkową za pośrednictwem wsporników 5, a pionowe obciążenia od sił docisku rolek jezdnych do szyn toru oraz siły od unoszenia ciagnika wprowadzono za pomocą wsporników 6.

\section{Kryteria oceny wytrzymałości oraz przyjęte obciążenia}

Ocenie wytrzymałościowej podlegają wartości naprężeń zredukowanych $\sigma_{\text {red }} \mathrm{W}$ poszczególnych elementach konstrukcji, które są wyznaczane zgodnie $\mathrm{z}$ hipotezą wytężeniową energii odkształcenia postaciowego Hubera-Misesa. Wartości naprężeń nie powinny przekroczyć wartości dopuszczalnych $\sigma_{\text {dop}}$. Jednak w przypadku określenia naprężeń dla materiałów plastycznych zjawisko lokalnej koncentracji naprężeń może nie być brane pod uwagę. Jeżeli obliczenia obejmują lokalne koncentracje naprężeń, to wówczas dopuszcza się, aby naprężenia teoretyczne przekraczały granicę plastyczności albo umowną granicę plastyczności przy 0,2 \% wydłużenia. Obszary lokalnych plastycznych deformacji związanych z koncentracją naprężeń powinny być jednak dostatecznie małe, aby po zdjęciu obciążenia nie pozostały znaczące trwałe deformacje.

Założono, że głównym materiałem konstrukcyjnym jest stal typu S355. Właściwości wytrzymałościowe stali przedstawiono w tablicy 1 [1].

Wartości naprężeń dopuszczalnych dla stali S355 z uwzględnieniem współczynnika bezpieczeństwa $\mathrm{s}=1,15$ zestawiono $\mathrm{w}$ tablicy 2 .

Elementy ciagnika (wspornik przedniej osi) wykonano z żeliwa sferoidalnego EN-GJS 600-3. W tablicy 3. przedstawiono jego parametry wytrzymałościowe. 
A safety factor of $\mathrm{s}=1.15$ was adopted for which the permitted stress value was $360 \mathrm{MPa} / 1.15=313 \mathrm{MPa}$.

Permitted stress values for type $\mathbf{S 3 5 5}$ steel Table 2

Wartości naprężeń dopuszczalnych dla stali typu S355

Tablica 2

\begin{tabular}{|l|l|l|}
\hline $\begin{array}{l}\text { Gatunek stali } \\
\text { Steel type }\end{array}$ & \multicolumn{2}{|l|}{ S355 } \\
\hline $\begin{array}{l}\text { Grubość[mm] } \\
\text { Thickness [mm] }\end{array}$ & $\leq 16$ & $\geq 16$ \\
\hline$\sigma_{\text {dop }}[\mathrm{MPa}]$ & $355 / 1,15=\mathbf{3 0 9}$ & $345 / 1,15=\mathbf{3 0 0}$ \\
\hline
\end{tabular}

Parametry wytrzymałościowe zastosowanego żeliwa sferoidalnego Tablica 3 Strength parameters of the ductile iron used Table 3

Zeliwo sferoidalne

\begin{tabular}{l|l|l}
\hline EN-GJS 600-3:1997 (GGG60) & Wytrzymałość na rozciaganie Rm [Mpa] & Granica plastyczności Re [Mpa] \\
\hline $25 \mathrm{~mm}-50 \mathrm{~mm} \mathrm{n}$ & 600 & 370 \\
$55 \mathrm{~m} m-100 \mathrm{~m} \mathrm{~m}$ & 600 & 360 \\
$105 \mathrm{~mm}-200 \mathrm{~mm}$ & 550 & $3<0$ \\
$205 \mathrm{~mm}-600 \mathrm{~mm}+$ & 550 & 340
\end{tabular}

The analyzed system presented in Fig. 2 has been tested for its ability to withstand the following forces:

- $300 \mathrm{kN}$ compression force along with vertical loads from track guiding rollers of $5 \mathrm{kN}$ per roller (Fig. 5.2)

- $150 \mathrm{kN}$ stretching force along with vertical loads from track guiding rollers of $5 \mathrm{kN}$ per roller (Fig.5.7)

- vertical force from rollers in the event of an emergency when the entire weight of the tractor rests on the rollers (each front roller puts $20 \mathrm{kN}$ of force on the analyzed structure, and each rear roller a $30 \mathrm{kN}$ force) (Fig. 5.9).

The bumper beam was exposed to $300 \mathrm{kN}$ compressive force and $150 \mathrm{kN}$ tensile force. Coupling elements were subjected to tension of $150 \mathrm{kN}$. (Research results will be presented in the second part of the study).

Additional simulation tests of the front chassis structure for longitudinal forces were performed - 370 $\mathrm{kN}$ compression after factory modernization of the axle support bracket and side reinforcements.

\section{Factory-made load-bearing elements of the tractor}

Figure 4 shows the main factory front load-bearing components of the tractor, where:

$\mathbf{1}$ - axle bracket

2 - reinforcing side beams.

Figure 4 a) shows the axle support brackets and side reinforcements of the tractor used in the production of the rail-road tractors in the years 2015 - 2017.

In IPS "TABOR", 8 rail-road tractor units were manufactured based on the tractors equipped with load-bearing elements made according to the solution in Fig. 4 a).
Przyjęto współczynnik bezpieczeństwa wynoszący $\mathrm{s}=1,15$ dla którego wartość naprężeń dopuszczalnych wynosi $360 \mathrm{MPa} / 1,15=313 \mathrm{MPa}$.

Analizowany układ przedstawiony na rys. 2 został sprawdzony pod kątem możliwości przenoszenia następujących obciążeń:

- ściskanie siłą $300 \mathrm{kN}$ wraz z obciążeniami pionowymi pochodzącymi od rolek $5 \mathrm{kN}$ na rolkę (Rys.5.2)

- rozciąganie siłą $150 \mathrm{kN}$ wraz $\mathrm{z}$ obciążeniami pionowymi pochodzącymi od rolek $5 \mathrm{kN}$ na rolkę (Rys.5.7)

- obciążenie pionowe pochodzące od rolek w przypadku awaryjnym gdy cała masa ciagnika spoczywa na rolkach (jedna przednia rolka obciąża analizowany układ siłą $20 \mathrm{kN}$, a tylna siłą $30 \mathrm{kN}$ ) (Rys.5.9).

Belkę zderzakową obciążono silą ściskającą $300 \mathrm{kN}$ oraz siłą rozciągającą $150 \mathrm{kN}$. Elementy sprzęgu poddano rozciąganiu siłą $150 \mathrm{kN}$. (Wyniki badań będą przedstawione $\mathrm{w}$ drugiej części opracowania).

Wykonano dodatkowe badania symulacyjne przedniej struktury nośnej na działanie sił wzdłużnych ściskanie siła $370 \mathrm{kN}$ po fabrycznej modernizacji wspornika osi i bocznych wzmocnień.

\section{Fabryczne elementy nośne ciągnika}

$\mathrm{Na}$ rysunku 4 przedstawiono główne fabryczne elementy nośne przedniej części ciągnika, gdzie oznaczono:

$\mathbf{1}$ - wspornik osi

2 - wzmocnienia boczne.

$\mathrm{Na}$ rysunku 4 a) pokazano wspornik osi i boczne wzmocnienia ciagnika stosowane w produkcji ciagników szynowo-drogowych w latach 2015 - 2017.

W IPS „Tabor” wytworzono 8 sztuk ciaggników szynowo-drogowych na ciagnikach bazowych wyposażonych w elementy nośne wykonane według rozwiązania rys. 4 a).

W 2018 roku producent ciągnika wdrożył zmodernizowane rozwiązania konstrukcyjne wspornika osi i bocznych wzmocnień wykonanych w postaci pokazanej na rys. 4 b) (po modernizacji).

Nowe rozwiązanie charakteryzuje się większą wytrzymałością na działanie sił wzdłużnych i momentów zginających, zwłaszcza ścian bocznych wspornika osi i bocznych wzmocnień ze względu na powiększone przekroje elementów nośnych wspornika osi i bocznych wzmocnień.

\section{Badany model ukladu przedniego przed mo- dernizacją}

Model przedstawiono na rys. 5.1. Do fabrycznego wspornika osi 1 zamocowano przednią strukturę nośną układu pociagowo-zderznego 2 , które dodatkowo 
In 2018, the tractor manufacturer implemented modernized structural solutions for the axle support brackets and side reinforcements made in the form shown in Fig. 4 b) (after modernization).

The new solution was characterized by greater resistance to longitudinal forces and torque, especially the side walls of the axle support bracket and side reinforcements due to the increased crosssections of the axle support brackets and side reinforcements.

\section{Tested model of the front axle system before modernization}

The model was shown in Fig. 5.1. The front axle support structure $\mathbf{2}$ was attached to the factory axle support bracket $\mathbf{1}$, which was additionally reinforced with side beams 3 . The factory side beams 4 reinforce the attachment of the axle support bracket to the engine body.

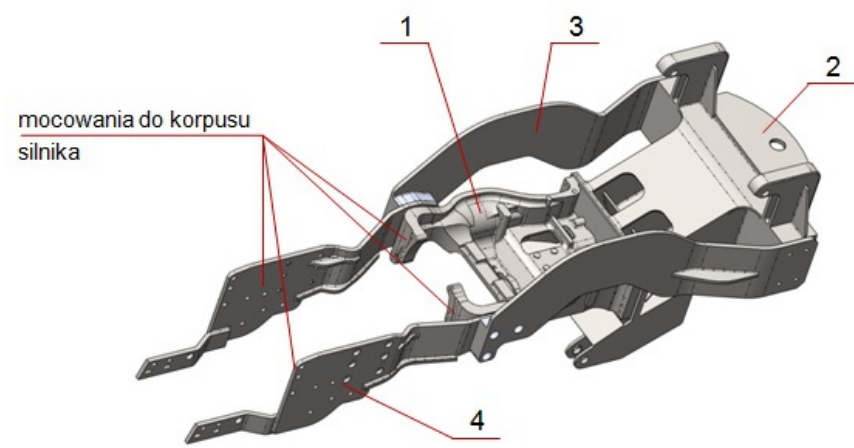

Rys. 5.1. Support structure of the front system without buffer beam and coupling

Description: mocowanie ... = element attacked to the engine body

Rys. 5.1. Struktura nośna przedniego układu bez belki zderzakowej i sprzęu

\subsection{Forces and results of simulation tests}

a) Front system compression $-300 \mathrm{kN}$

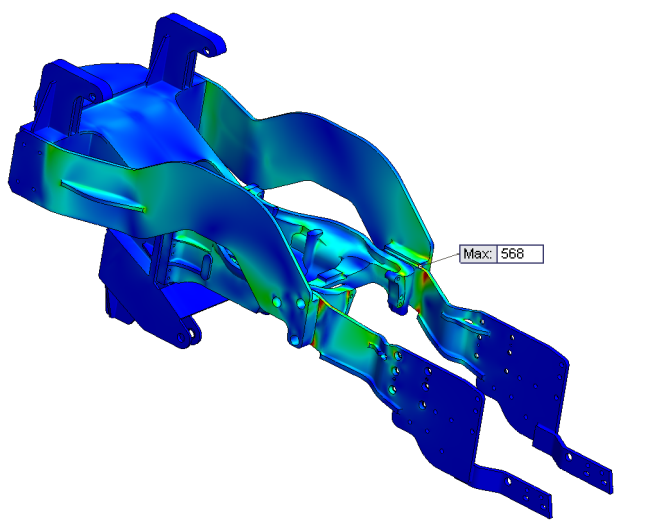

Rys. 5..3. Reduced stress distribution Rozkład naprężeń zredukowanych wzmocniono belkami górnymi 3. Fabryczne belki dolne 4 stanowią wzmocnienie mocowania wspornika osi do korpusu silnika.

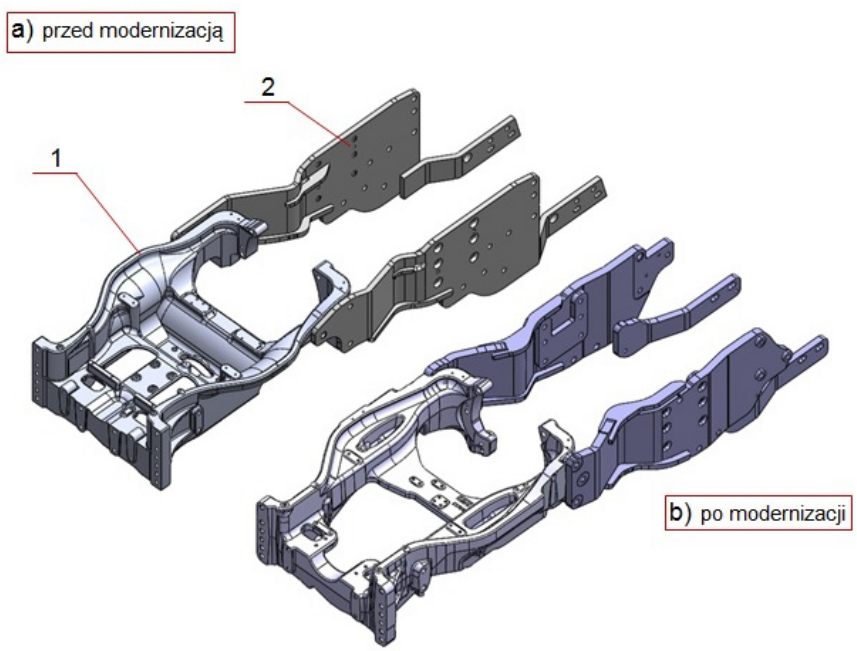

Rys.4. Factory components of the load-bearing chassis parts Description: a) przed modernizacją = before modernization; b) po modernizacji $=$ after modernization

Rys. 4. Fabryczne części składowe struktury nośnej

\subsection{Obciążenia oraz wyniki badań symulacyjnych a) ściskanie układu przedniego - $300 \mathrm{kN}$}

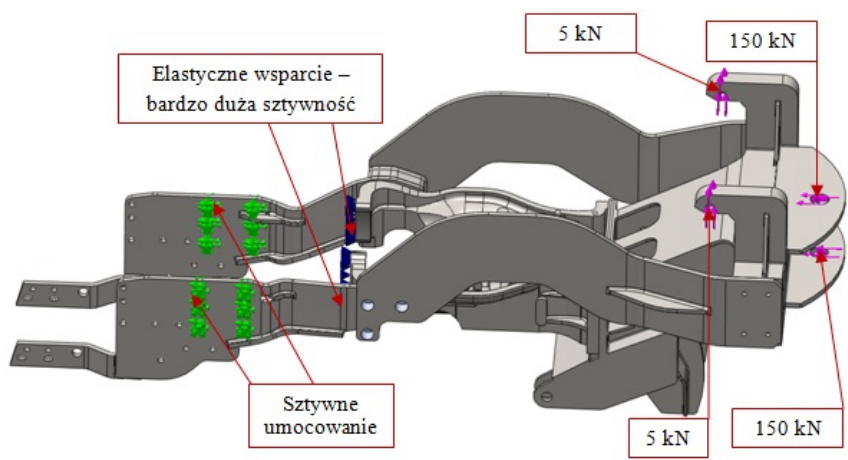

Rys. 5.2. Forces and mounting

Description: elastyczne wsparcie $=$ elastic reinforcement, highly rigid; sztywne mocowanie $=$ rigid attachment

Rys. 5.2 Obciążenia i umocowania

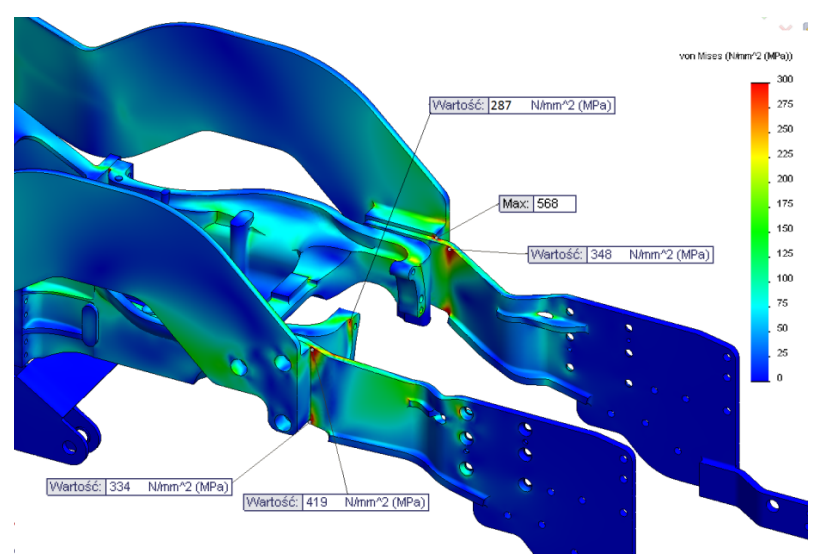

Rys. 5.4. Reduced stress distribution - in detail Rozkład naprężeń zredukowanych - szczegół 


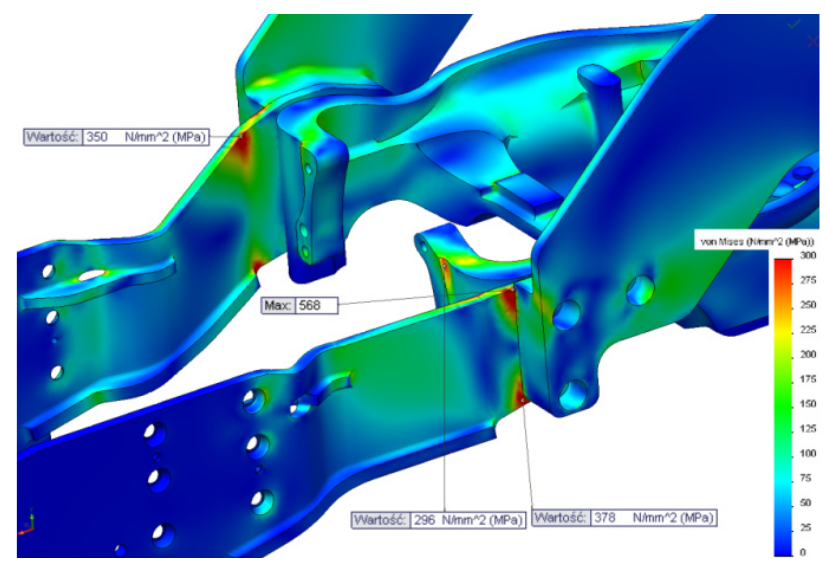

Rys. 5.5. Reduced stress distribution - in detail Rozkład naprężeń zredukowanych - szczegół

b) stretching force on the front system $-150 \mathrm{kN}$

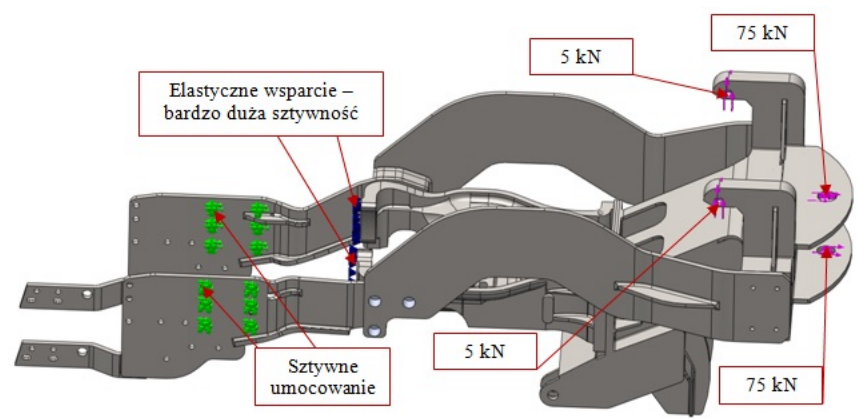

Rys. 5.7. Forces and mounting

Description: elastyczne wsparcie = elastic reinforcement, highly rigid; sztywne mocowanie $=$ rigid attachment

Obciążenia i umocowania

c) Vertical forces in the front system $-40 \mathrm{kN}$

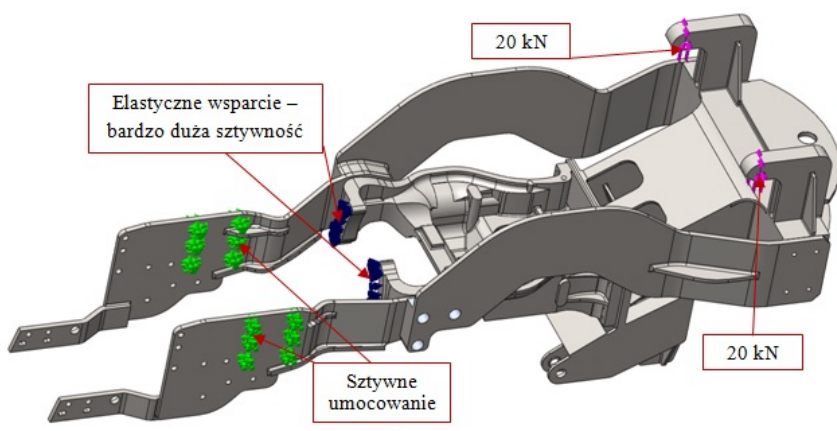

Rys. 5.9. Reduced stress distribution

Description: elastyczne wsparcie = elastic reinforcement, highly rigid; sztywne mocowanie $=$ rigid attachment

Rozkład naprężeń zredukowanych

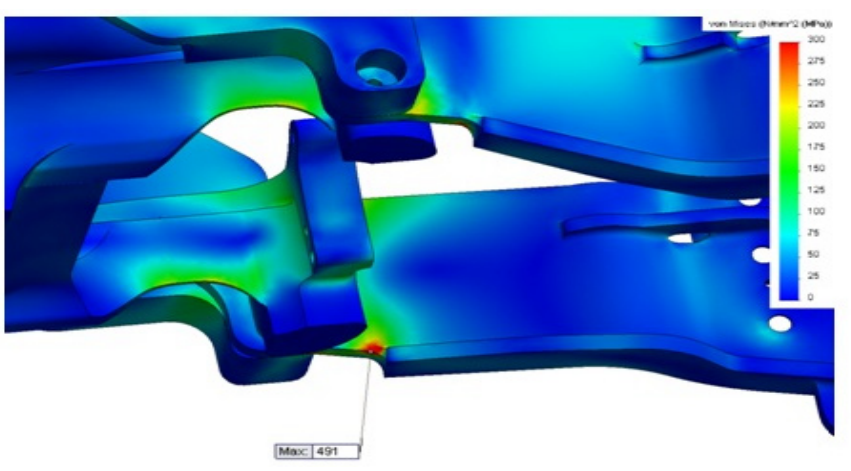

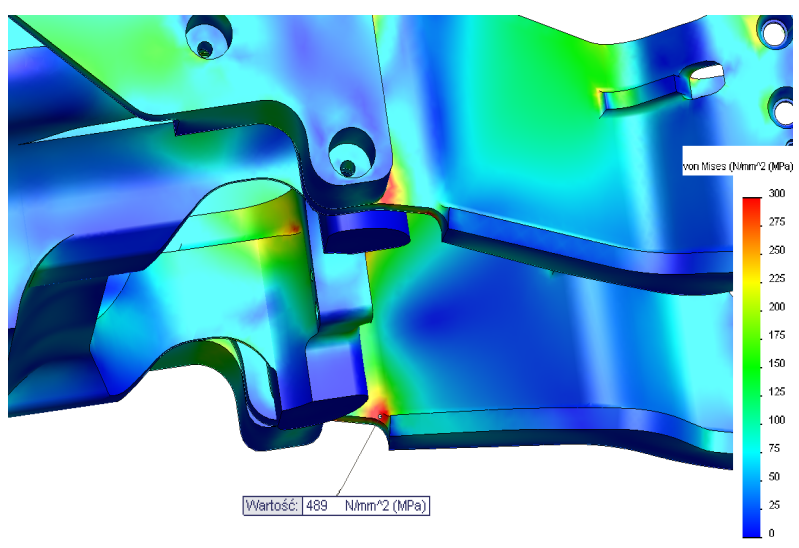

Rys. 5.6. Reduced stress distribution - in detail Rozkład naprężeń zredukowanych - szczegół

b) rozciaganie uktadu przedniego - $150 \mathrm{kN}$

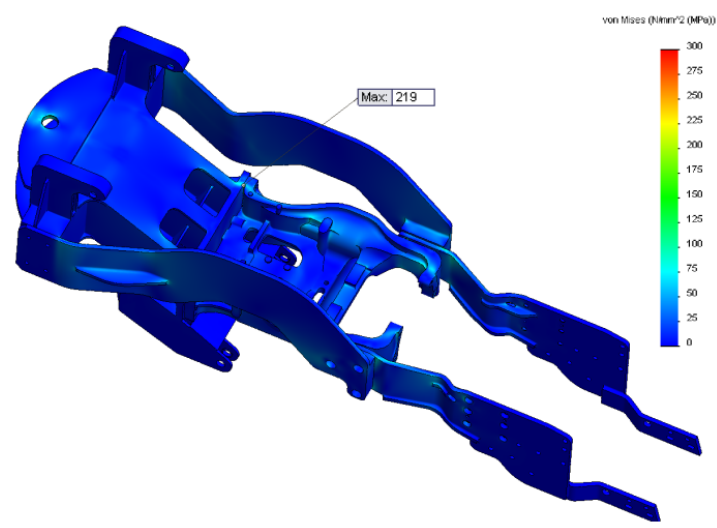

Rys. 5.8. Reduced stress distribution Rozkład naprężeń zredukowanych

c) Obciqżenie pionowe przedniego układu - $40 \mathrm{kN}$

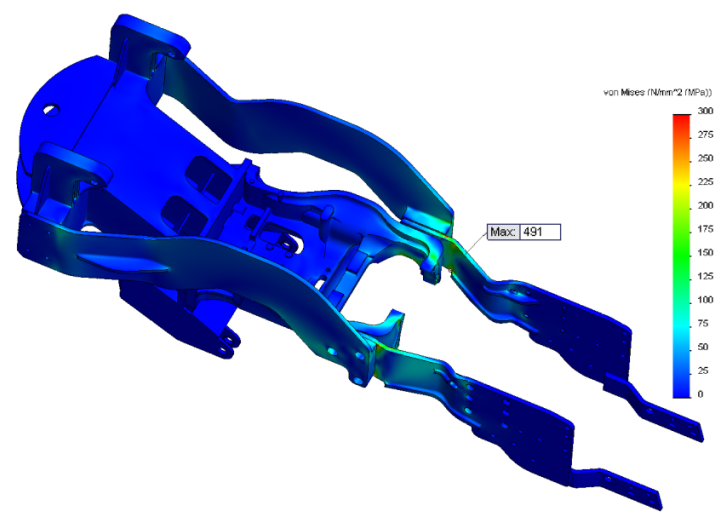

Rys. 5.10. Reduced stress distribution

Rozkład naprężeń zredukowanych
Rys. 5.11. Reduced stress distribution Rozkład naprężeń zredukowanych 
6. Tested model of the front system after modernization

\subsection{Compressive force of $300 \mathrm{kN}$}

\section{a) Model variant I}

The variant I model consisting of front flat bracket element $\mathbf{1}$, factory axle support bracket $\mathbf{2}$ and factory side reinforcements $\mathbf{3}$ was tested (Fig. 6.1).

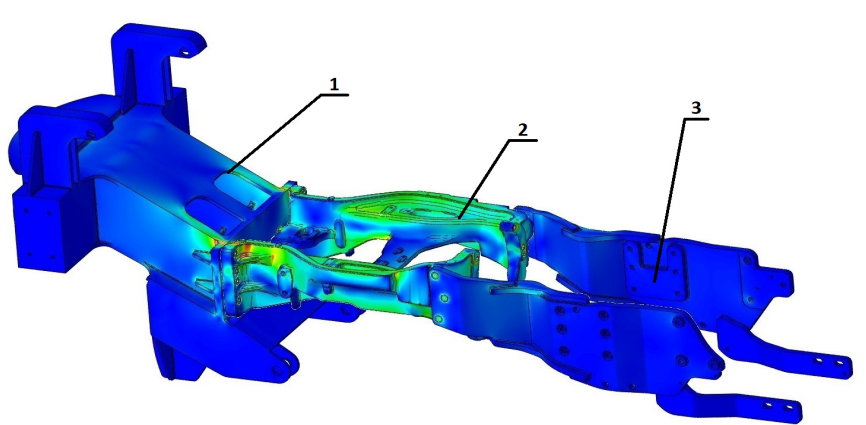

Rys. 6.1. System after modernization Model po modernizacji

The test results were provided in figures 6.2 and 6.3.

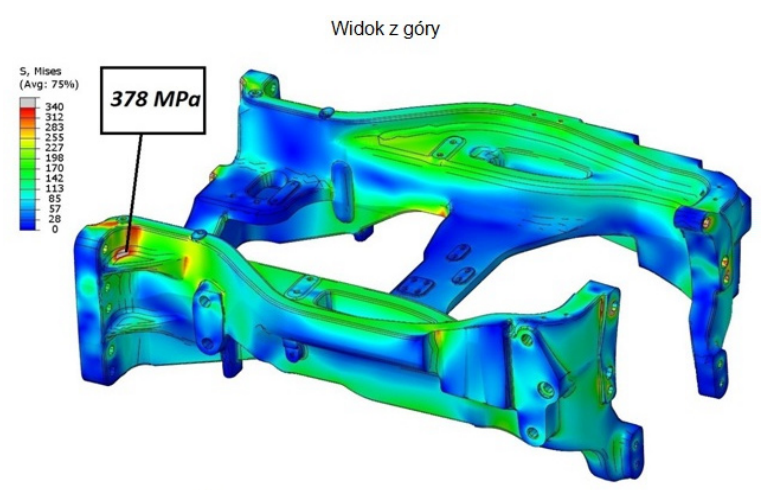

\section{Badany model układu przedniego po moderni- zacji}

\section{1. Ściskanie silą $300 \mathrm{kN}$}

\section{a) Model wariant I}

Badaniom poddano model wariant I złożony z przedniej skrzyni 1, fabrycznego wspornika osi 2 i fabrycznych wzmocnień dolnych 3 (rys. 6.1).

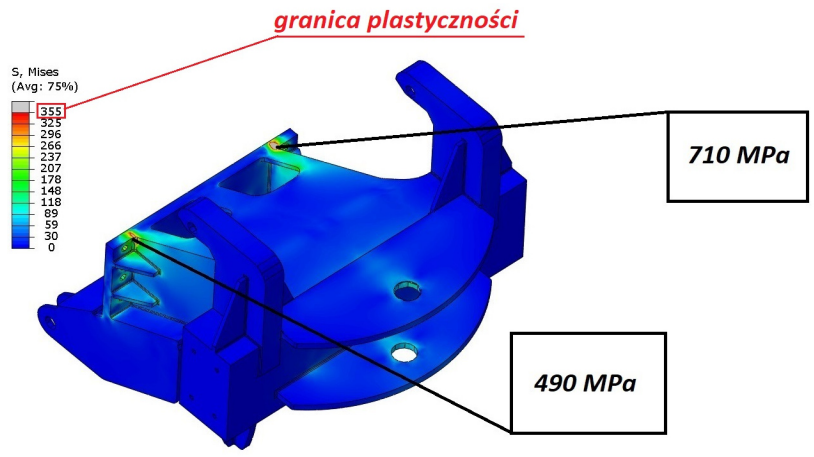

Rys. 6.2. Reduced stress distribution (front part - pos.1)

Description: granica plastyczności $=$ yield point

Rozkład naprężeń zredukowanych (skrzynia przednia - poz.1)

Wyniki badań przedstawiono na rysunkach 6.2 i 6.3 .

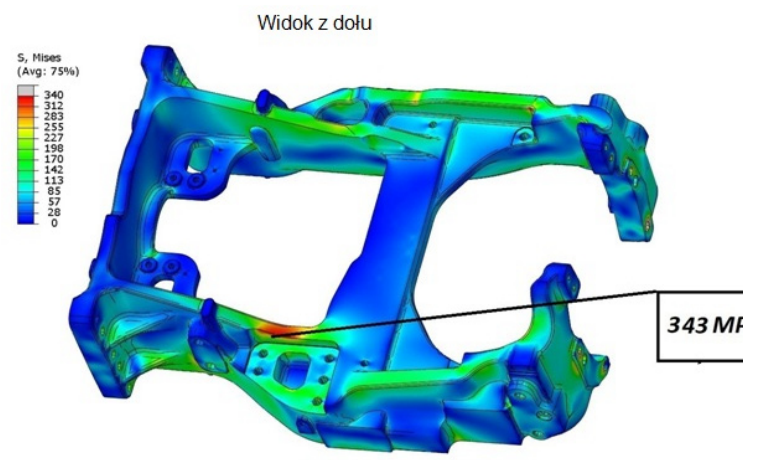

Rys. 6.3. Reduced stress distribution (axle support bracket - pos.2)

Rozkład naprężeń zredukowanych (wspornik osi - poz.2)

\section{b) Model variant II}

The tests were performed on the model variant II. This model consisted of the following elements:

- front bracket - 1

- factory-made support bracket - $\mathbf{2}$

- factory-made side beams $\mathbf{- 3}$

- additional topside reinforcements $\mathbf{- 4}$.

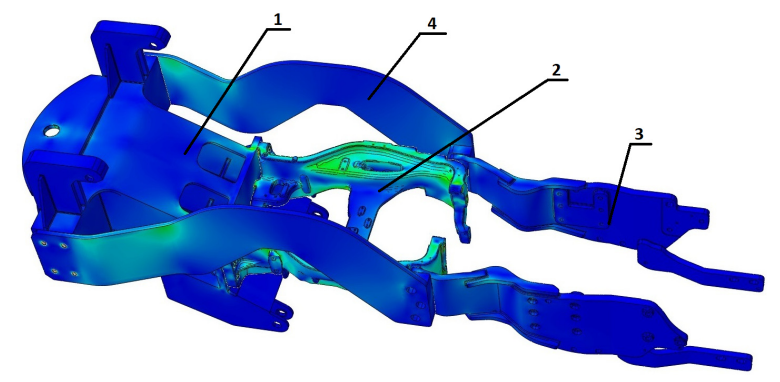

Rys. 6.4. Model after modernization with additional topside reinforcement

Model po modernizacji z dodatkowym wzmocnieniem górnym

\section{b) Model wariant II}

Badania wykonano na modelu wariant II. Model złożono z następujących elementów:

- przednia skrzynia - 1

- fabryczny wspornik - 2

- fabryczne wzmocnienia dolne $\mathbf{- 3}$

- dodatkowe wzmocnienia górne - 4 .

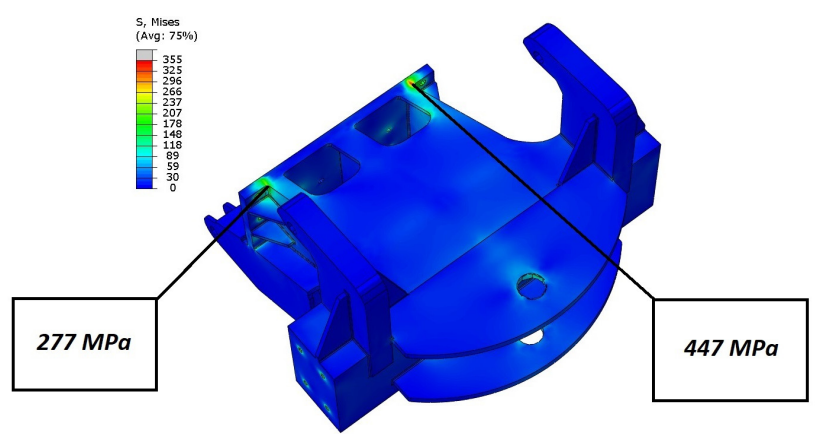

Rys. 6.5. Reduced stress distribution (front part - pos.1) Rozkład naprężeń zredukowanych (skrzynia przednia - poz.1) 
The test results were shown in Figures 6.5 and 6.6.

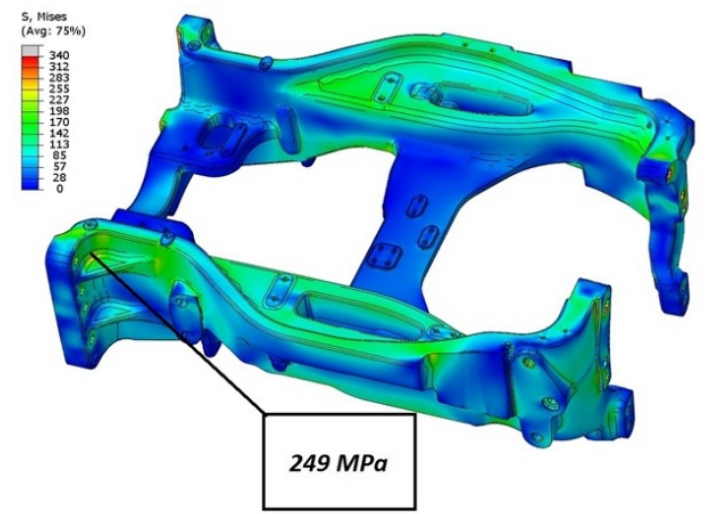

Wyniki badań przedstawiono na rysunkach 6.5 i 6.6 .

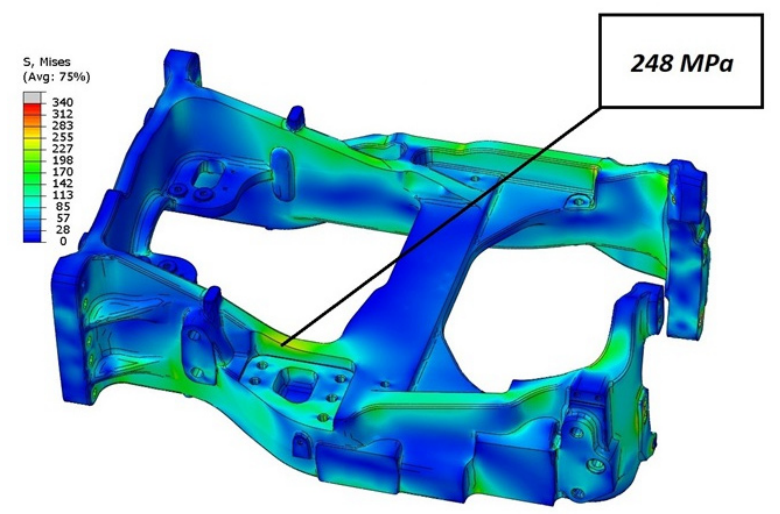

Rys. 6.6. Reduced stress distribution (axle support bracket - pos.2) Rozkład naprężeń zredukowanych (wspornik osi - poz.2)

The maximum permitted stress in the axle support bracket was not exceeded when compressed with the force of $300 \mathrm{kN}$.

\subsection{Compression with a force of $370 \mathrm{kN}$ - variant III}

The variant III model was tested.

The test results were shown in figures 6.7 and 6.8 .
Nie zarejestrowano przekroczenia maksymalnych naprężeń dopuszczalnych w wsporniku osi przy ściskaniu siłą $300 \mathrm{kN}$.

\section{2. Ściskanie silą $370 \mathrm{kN}$ - wariant III}

Badaniom poddano model wg wariantu II.

Wyniki badań przedstawiono na rysunkach 6.7 i 6.8 .

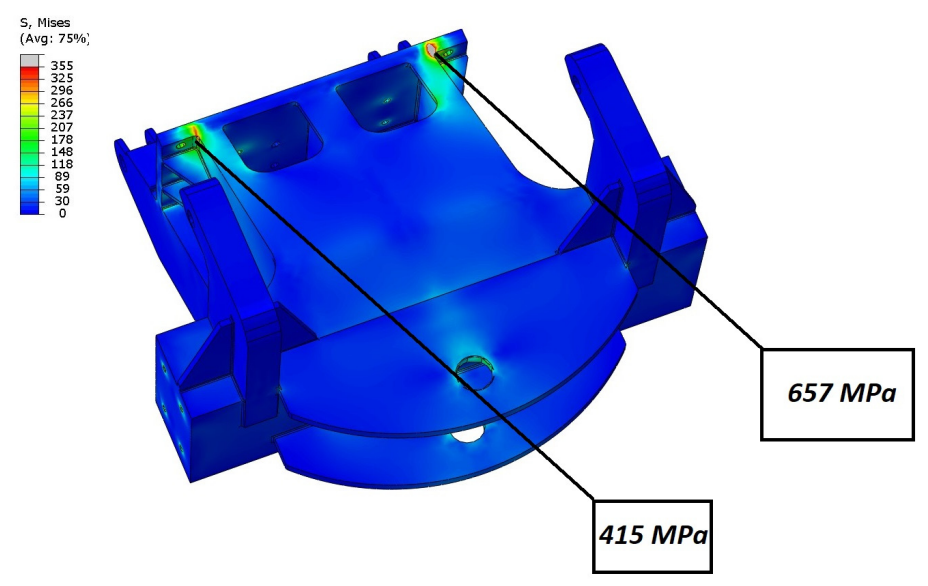

Rys. 6.7. Reduced stress distribution (front part - pos.1) Rozkład naprężeń zredukowanych (skrzynia przednia - poz.1)
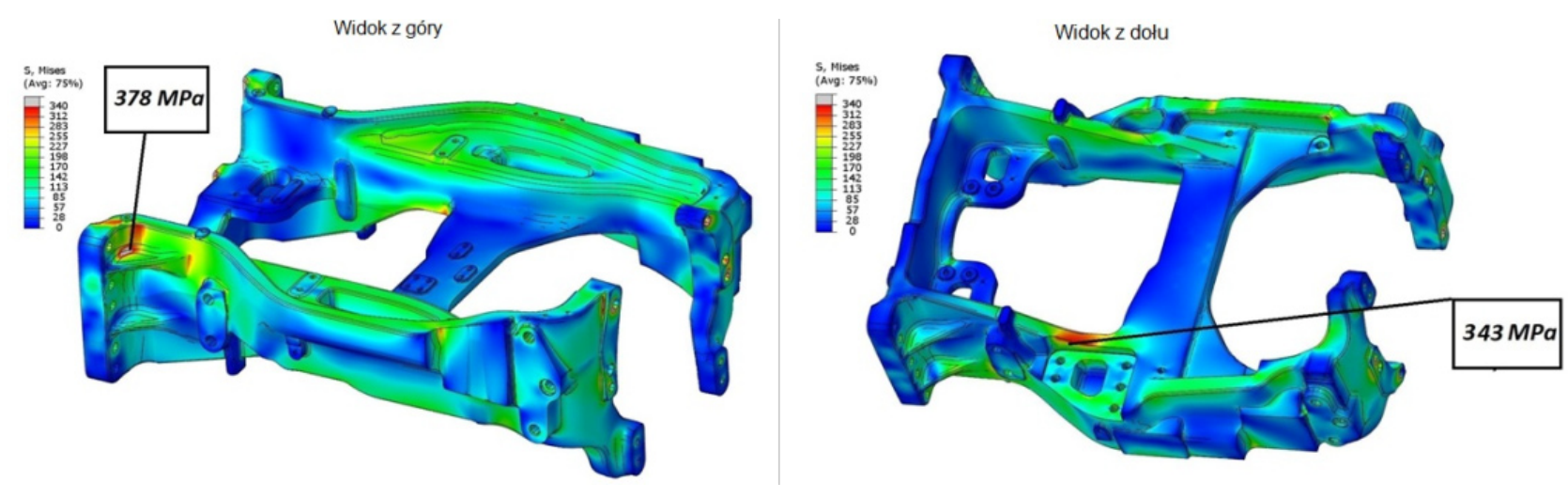

Rys. 6.8. Reduced stress distribution (axle support bracket - pos.2) Rozkład naprężeń zredukowanych (wspornik osi - poz.2 


\section{Discussion of the results}

7.1.The front coupling-buffer system

a) Compression forces in the front coupling-buffer system

The coupling-buffer system was subject to a compression test before modernization, the system consisted of a front bracket, axle support bracket, side and upper reinforcing elements (Fig. 5.2).

The distribution of maximum stress values was shown in figures 5.3, 5.4, 5.5 and 5.6. Maximum stress values of $568 \mathrm{MPa}$ and $560 \mathrm{MPa}$ were recorded in the locations where top and side brackets were connected, which exceeded the permitted stress level of $\mathrm{R}_{\mathrm{e}} \leq 309 \mathrm{MPa}$ but did not exceed the short-term tensile strength $\mathrm{R}_{\mathrm{m}} \leq 630 \mathrm{MPa}$ (before modernization), additional side reinforcements were used to reduce the maximum stress concentration values to the safe permitted level $\delta_{\text {dop }} \leq 309 \mathrm{Mpa}$.

\section{b) Stretching forces in the front system}

The previously compressed model was then subjected to the tensile test. The distribution of reduced stress values was shown in Fig. 5.7.

The distribution of reduced stress was shown in Fig. 5.8. Maximum reduced stress values reached up to $219 \mathrm{MPa}$, which was still less than $\mathrm{R}_{\mathrm{e}}=309 \mathrm{MPa}$.

\section{c) Frontal forces in the front system}

The vertical forces occur in the system during emergency lifting of the tractor until the tires break their contact with the ground, such as when replacing tires or driving over an obstacle that exceeds the lower gauge limit, especially by the wide rear tires. The distribution of forces and their location was shown in Figure 5.9.

The maximum reduced stress values were shown in Figures 5.10 and 5.11. Maximum stress concentration up to $491 \mathrm{MPa}$ occurred at the locations where the lower and side reinforcements were connected. After the installation of additional side reinforcements, the measured stress level dropped below the limit value of $\mathrm{Re}=309 \mathrm{MPa}$.

\section{d) Compression of the front coupling system -} after modernization

The first variant of drive system without topside reinforcements was subjected to testing. The tested model was shown in Fig. 6.1. The level of registered maximum stress values in the bracket pos.1 fig.6.1 was $710 \mathrm{MPa}$ and $490 \mathrm{MPa}$ in the area where the element attached to the axle support bracket pos. 2 fig.6.1. In the axle bracket, on the other hand, the highest stress values were recorded at $378 \mathrm{MPa}$ also in the area of the attachment to the bracket and in the bottom area of the bracket at $343 \mathrm{MPa}$ (Fig. 6.3). The large difference in stress values recorded on both sides of the chassis is the result of the difference in longitudinal stiffness of the side profiles of the axle bracket casting. The forces occurring in the axle support bracket slightly exceed the permissible stress

\section{Komentarz do wyników badań}

\subsection{Przedni układ pociągowo-zderzny}

a) Ściskanie przedniego układu pociągowozderznego

Próbie ściskania poddano układ pociagowo-zderzny przed modernizacją złożony $\mathrm{z}$ przedniej skrzyni, wspornika osi, dolnych i górnych belek wzmacniających (rys.5.2).

Rozkład naprężeń maksymalnych przedstawiono na rysunkach 5.3, 5.4, 5.5 i 5.6. Maksymalne naprężenia o wartości $568 \mathrm{MPa}$ i $560 \mathrm{MPa}$ zarejestrowano w miejscach połączenia wzmocnień górnych z wzmocnieniami dolnymi, które przekraczały naprężenia dopuszczalne $\mathrm{R}_{\mathrm{e}} \leq 309 \mathrm{MPa}$ lecz nie przekraczały wytrzymałości doraźnej $\mathrm{R}_{\mathrm{m}} \leq 630 \mathrm{MPa}$ (dla obciążeń nadzwyczajnych). Na pojazdach wytwarzanych do 1995 roku (przed modernizacja) stosowano dodatkowe wzmocnienia dolne $\mathrm{w}$ celu obniżenia wartości maksymalnych spiętrzeń naprężeń do poziomu bezpiecznego $\delta_{\text {dop }} \leq 309 \mathrm{Mpa}$.

\section{b) Rozciąganie przedniego układu pociągowego}

Próbie rozciagania poddano model ściskany. Rozkład sił i miejsca przyłożenia pokazano na rys.5.7.

Rozkład naprężeń zredukowanych przedstawiono na rys.5.8. Maksymalne naprężenia zredukowane osiągnęły wartość $219 \mathrm{MPa}$, co jest mniejsze od $\mathrm{R}_{\mathrm{e}}=309$ $\mathrm{MPa}$.

\section{c) Obciążenia pionowe przedniego ukladu}

Obciążenia pionowe urządzenia występują przy awaryjnym unoszeniu ciagnika do oderwania opon od podłoża w celu wymiany opon lub przejazdu nad przeszkodą wynikającą z przekroczenia zarysu dolnego skrajni, szczególnie przez szerokie opony tylne. Rozkład obciążeń i miejsca przyłożenia pokazano na rysunku 5.9.

Maksymalne obciążenia zredukowane przedstawiono na rysunkach 5.10 i 5.11. Maksymalne spiętrzenie naprężeń do wartości $491 \mathrm{MPa}$ wystapiły w miejscach połączenia wzmocnień dolnych z górnymi. Po zabudowie dodatkowych wzmocnień dolnych poziom naprężeń osiąnął wartość poniżej granicy $\mathrm{R}_{\mathrm{e}}=309$ $\mathrm{MPa}$.

\section{d) Ściskanie przedniego ukladu pociągowego - po} modernizacji

Badaniom poddano pierwszy wariant kompletacji układu pociagowego, bez wzmocnień górnych. Badany model przedstawiono na rys.6.1. Poziom zarejestrowanych maksymalnych naprężeń w skrzyni poz.1 rys.6.1 wynosi $710 \mathrm{MPa}$ i $490 \mathrm{MPa}$ w okolicy mocowania skrzyni do wspornika osi poz.2 rys.6.1. Natomiast we wsporniku osi największe naprężenia zanotowano na poziomie $378 \mathrm{MPa}$ również $\mathrm{w}$ okolicy mocowania skrzyni do wspornika oraz w strefie dolnej wspornika na poziomie $343 \mathrm{MPa}$ (rys.6.3). Duża różnica wartości naprężeń zarejestrowana po obu stronach skrzyni jest wynikiem różnicy sztywności wzdłużnej bocznych profili odlewu wspornika osi. 
level of $\mathrm{R}_{\mathrm{e}}=340 \mathrm{MPa}$ for ductile iron, for irregular force of $300 \mathrm{MPa}$.

No stress values exceeding the permitted stress level $\delta_{\text {dop }}=309 \mathrm{MPa}$ was found In the lower side beams item 3 fig. 6.4 of the tested model for S355 steel with a thickness greater than $16 \mathrm{~mm}$.

In the second variant of the examined model Fig. 6.1, the impact of topside reinforcements item 4 was deemed to be transferring the $300 \mathrm{kN}$ compressive load. The level of recorded maximum stress values was shown in Figures 6.5 and 6.6.

Local stress concentration in the bracket at the points of attachment to the front chassis increased from 710 $\mathrm{MPa}$ to $447 \mathrm{MPa}$ and from $490 \mathrm{MPa}$ to $277 \mathrm{MPa}$ after installing additional topside reinforcements, and in the axle bracket the stress level dropped from 378 $\mathrm{MPa}$ to $249 \mathrm{MPa}$ and from $343 \mathrm{MPa}$ to $248 \mathrm{MPa}$.

In the third tested variant of the model taking into account upper reinforcements, a compressive force of $370 \mathrm{kN}$ was applied. The stress level in the tested components of the model was shown in Fig. 6.7, $6.8 \mathrm{a}), 6.8 \mathrm{~b})$. The axle bracket has not exceeded the permissible stress values $\delta_{\text {dop }}=340 \mathrm{MPa}$. However, local stress concentration in the front chassis was at the upper limit of ultimate strength $R_{m}=470 \mathrm{MPa}-$ $630 \mathrm{MPa}$.

The modernization of the front axle bracket structure and side reinforcements, attached to the tractor engine, implemented by the base tractor manufacturer, significantly influenced the resistance of the front drive system to longitudinal forces, increasing the safety margin of the front supporting structure of the coupling-buffer system.

The modernized front axle bracket made it possible to forgo using the additional side reinforcements used in rail-road tractors before the axle bracket modernization.

\section{Bibliography / Bibliografia}

1] PN-EN 10025 Wyroby walcowane na gorqco niestopowych stali konstrukcyjnych. Warunki techniczne dostawy.

[2] PN-EN 15551 Kolejnictwo. Zderzaki.

[3] Medwid M., Daszkiewicz P., Czerwiński J., Jakuszko W. - Sieć Badawcza Łukasiewicz-Instytut Pojazdów Szynowych „,Tabor”, Kazimierczak E.- CLAAS Polska: Ciagnik szynowo-drogowy z napędem spalinowo-elektrycznym. Pojazdy Szynowe, 2019, nr 3.

[4] Medwid M., Jakuszko W., Kazimierczak E.: Cechy konstrukcyjne ciagnika bazowego wybranego do adaptacji na pojazd szynowo-drogowy nowej generacji. Pojazdy Szynowe, 2017, nr 3.

[5] Medwid M., Stawecki W., Czerwiński J., Jakuszko W., Kazimierczak E.: Modelowanie struktury manewrowego ciqgnika szynowo-drogowego CLAAS ARION 620. Pojazdy Szynowe, 2017, nr 2.
Naprężenia występujące w wsporniku osi w niewielkim stopniu przekraczają poziom naprężeń dopuszczalnych $\mathrm{R}_{\mathrm{e}}=340 \mathrm{MPa}$ dla żeliwa sferoidalnego, dla obciążenia nadzwyczajnego $300 \mathrm{MPa}$.

We wzmocnieniach dolnych poz. 3 rys.6.4 badanego modelu nie stwierdzono poziomu naprężeń przekraczających naprężenia dopuszczalne $\delta_{\text {dop }}=309 \mathrm{MPa}$ dla stali S355 o grubości większej od $16 \mathrm{~mm}$.

W drugim wariancie badanego modelu rys.6.1 uwzględniono udział wzmocnień górnych poz. $4 \mathrm{~W}$ przenoszeniu obciążenia ściskającego o wartości 300 $\mathrm{kN}$. Poziom zarejestrowanych naprężeń maksymalnych przedstawiono na rys.6.5 i 6.6 .

Lokalne spiętrzenie naprężeń w skrzyni w miejscach mocowania do wspornika zwiększyło się odpowiednio z $710 \mathrm{MPa}$ do $447 \mathrm{MPa}$ i z $490 \mathrm{MPa}$ do $277 \mathrm{MPa}$ po zamontowaniu dodatkowych górnych wzmocnień, a we wsporniku osi poziom naprężeń obniżył się $\mathrm{z}$ wartości $378 \mathrm{MPa}$ do $249 \mathrm{MPa}$ oraz z $343 \mathrm{MPa}$ do $248 \mathrm{MPa}$.

$\mathrm{W}$ trzecim wariancie badań modelu uwzględniającego wzmocnienia górne przyłożono siłę ściskającą o wartości $370 \mathrm{kN}$. Poziom naprężeń w badanych elementach składowych modelu pokazano na rys.6.7, $6.8 \mathrm{a}), 6.8 \mathrm{~b})$. W wsporniku osi nie zanotowano przekroczenia naprężeń dopuszczalnych $\delta_{\text {dop }}=340 \mathrm{MPa}$. Natomiast lokalne spiętrzenia naprężeń w skrzyni są $\mathrm{w}$ górnej granicy wytrzymałości doraźnej $\mathrm{R}_{\mathrm{m}}=470$ $\mathrm{MPa}-630 \mathrm{MPa}$.

Wdrożona przez producenta ciagnika bazowego modernizacja konstrukcji wspornika przedniej osi i dolnych wzmocnien, mocowanych do silnika ciagnika, w istotny sposób wpłynęła na odporność przedniego układu pociagowego na działanie sił wzdłużnych podnosząc zapas bezpieczeństwa przedniej konstrukcji nośnej układu pociagowo-zderznego.

Zmodernizowany wspornik przedniej osi umożliwił rezygnację $\mathrm{z}$ dodatkowych wzmocnień dolnych stosowanych $\mathrm{w}$ ciagnikach szynowo-drogowych przed modernizacją wspornika osi.

[6] Bryk K., Lukaszewski K., Medwid M.: Symulacyjne badania bezpieczeństwa ruchu ciagnika szynowodrogowego CLAAS ARION 620. Międzynarodowa Konferencja Naukowa TRANSPORT XXI WIEKU. Artamów, 30.08. $\div 02.09 .2016$.

[7] Medwid M.: Hybrydowe pojazdy kolejowo-drogowe zaprojektowane $i$ wytwarzane $w$ Polsce. Technika Transportu Szynowego, 2005, nr 7-8.

[8] Medwid M., Stawecki W., Czerwiński J., Jakuszko W.: Wielozadaniowy ciagnik szynowo-drogowy nowej generacji. Pojazdy Szynowe, 2016, nr 3. 